\title{
Congenital Macrocephaly
}

National Cancer Institute

\section{Source}

National Cancer Institute. Congenital Macrocephaly. NCI Thesaurus. Code C35653.

An abnormal enlargement of the head, including the scalp, the cranial bone, and the contents of the cranium that is present at the time of birth; representative examples include tuberous sclerosis, neurofibromatosis, and various other genetic causes. 